\title{
Seasonality in The Monthly Returns of Large and Small Stocks
}

\author{
Shaikh A. Hamid \\ Southern New Hampshire University
}

The seasonality of large stocks and small stocks have been looked at separately by researchers, but the seasonality of the two types of stocks have not been compared to each other. This paper looked at the seasonality of the two types of stocks from the perspective of means and standard deviations of monthly returns from 1926-2013. We find a negative September effect in the monthly returns of large stock. We find a positive January effect and a negative October effect for small stocks. We also find seasonality in terms of volatility for both large and small stocks.

\section{INTRODUCTION}

In the long run stocks have provided the highest returns among various asset classes. It would be interesting to explore to what extent the markets for large and small stocks are efficient, to what extent are they efficiently priced. As a proxy for efficiency we use seasonality in the monthly total returns of large and small stocks. We will not expect to find seasonal patterns in monthly returns in an efficiently priced market. The existence of seasonality will point to inefficiency. This aspect has been explored by researchers using various types of stocks from various countries. But we use a much larger data set, and we present comparison in seasonality in terms of large and small stocks, and in terms of mean of monthly returns and in terms of volatility of monthly returns. Our understanding from exhaustive literature survey is that seasonality with respect to volatility of monthly returns has not been explored.

\section{LITERATURE SURVEY ON SEASONALITY IN STOCK RETURNS}

Since exploration of comparative monthly seasonality in the two types of stocks is an important aspect of this study, we review previous work in this regard. Since the time stock exchanges were first established, traders and investors have exhaustively looked for patterns in stock prices that they could exploit to realize superior returns. As early as 1900, Bachelier characterized security prices as being efficient. Over thirty years later Cowles (1933) documented the inability of forty-five professional agencies to forecast stock prices. The conclusion was that stock prices are random - in general they do not exhibit patterns. This was followed by the researches of Working (1934), Cowles and Jones (1937), Kendall (1953), and Osborne $(1959,1962)$. They documented that stock and commodity prices behave like a random walk - as if they are independent random drawings. Samuelson (1965) and Mandelbrot (1966). Fama (1965) also contributed to this body of literature which came to be termed the 'random walk hypothesis'. In 1970, Fama came up with the 'efficient markets hypothesis' (EMH). This hypothesis postulates that stock prices reflect all available information; they change in response to new information; 
since new information by definition cannot be deduced from previous information, new information must be independent over time; if the arrival of new information is random, stock price changes are random the changes cannot be anticipated; hence it is not possible to generate risk-adjusted abnormal returns from stocks.

The overall finding is that it is difficult to earn above-average profits by trading on publicly available information because it is already incorporated in securities prices. However, some researchers have been able to identify profitable opportunities or anomalies. These findings go against the concept of efficient markets. The believers of the new camp may possibly be increasing. Among the various anomalies discovered, the January effect is possibly the most well-known. It has been documented for financial markets across the globe. The first evidence of returns in January exceeding those of other months comes from Wachtel (1942). After over thirty-three years, Officer (1975) presented further evidence followed by Rozeff and Kinney (1976). These findings challenged the concept of efficient markets hypothesis that securities markets reflect all available information and hence it is not possible to garner positive riskadjusted returns.

A major finding that comes out of the researches is the size effect: small-capitalization firms earn higher returns than large-capitalization firms. Banz (1981) and Reinganum (1981) were the first researchers to discover the small-firm effect. Their finding was supported by Brown, Keim, Kelidon and Marsh (1983), Kato and Schallheim (1985), Fama and French (1992), Berk (1995), Baker and Limmack (1998), and Garza-Gromez, Hodoshima and Kunimura (1998). Keim (1983), Blume and Stambaugh (1983) and Roll (1983) find that majority of the return of small-capitalization stocks occurs in January -in the first two weeks of the month. This phenomenon came to be known as the small-firm-in-January effect. Keim found that small firms outperformed large firms in every year from 1963 to 1979.

It has been argued that the January effect is most pronounced for the smaller firms because the small firms are more volatile and more prone to price declines and hence more subject to tax-loss selling.

Arbel and Strebel (1983) found that the January effect was largest for firms neglected by institutional investors. This was termed the neglected-firm effect. The hypothesis is that small firms tend to be neglected by large institutional traders; this causes information deficiency which makes them riskier and hence requiring higher returns.

Haugen and Jorion (1996) use data for the stocks in New York Stock Exchange from 1926 to 1993 and find that for smaller stocks January returns are significantly larger than for other months. This work also indicates that excess returns in January may be declining in later years. This was also found by Riepe (1998, 2001).

Agrawal and Tandon (1994) find for nineteen countries covering data for 1970's and 1980's that the mean January returns are high - significantly high for eleven countries. Giovanis (2009) look at calendar effects in fifty-five stock market indices.

A large number of researchers have explored monthly seasonality for various countries and regions that include Australia, Africa, China, India, Kuwait, Lithuania, Macedonia, Malaysia, Mauritius, PacificBasin countries (Japan, Korea, Taiwan, Hong Kong, Singapore), Spain, South-East Asia, UK, and Vietnam. For brevity, the detailed references are not provided. Angelovska (1914) and Friday and Hoang (2015) include in their references many of these studies.

We intend to contribute to this growing literature by exploring seasonality in monthly returns of large stocks over a much longer period (January 1926 to December 2013). The next section describes the descriptive statistics of large stocks, followed by results of analyses of monthly seasonality, pattern of returns during Republican and Democratic presidential months, behavior of returns during expansion and recession, and average returns during crises. Some tentative conclusions follow. 


\section{HYPOTHESES}

We study the seasonality in terms of monthly percentage changes from three approaches:

1. If the mean of monthly total returns is different from zero for the sample as well as for each month in the sample. We subject the mean percentage change for a given month $i$ to the following hypothesis test: $\mathrm{H}_{0}: \mu_{i}=0$ vs. $\mathrm{H}_{0}: \mu_{i} \neq 0$.

2. If the mean of the monthly total returns for a month is significantly different from the mean of the other 11 months stacked. We conduct the following hypothesis test for a given month $i: \mathrm{H}_{0}: \mu_{i}=$ $\mu_{j}$ vs. $\mathrm{H}_{0}: \mu_{i} \neq \mu_{j}$, where $\mathrm{j}=\{1,2, \ldots, \mathrm{i}-1, \mathrm{i}+1,,,,, 11,12\}$. Since the variances for the periods $\mathrm{i}$ and $\mathrm{j}$ were unequal in many cases, we used the more conservative t-test assuming unequal variances.

3. If the variance of the monthly total returns for a given month is different from the variance of the other eleven months stacked. We conduct the following hypothesis test for a given month $i: \mathrm{H}_{0}$ : $\sigma_{i}^{2}=\sigma_{j}^{2}$ vs. $H_{0}: \sigma_{i}^{2} \neq \sigma_{j}^{2}$, where $\mathrm{j}=\{1,2, \ldots, \mathrm{i}-1, \mathrm{i}+1,,,,, 11,12\}$.

In addition to standard t-test which assumes normal distribution of the data, we also use KruskalWallis non-parametric test which tests for differences among several population medians, and does not depend on normal distribution of data. We also use Mood's Median Test which performs a nonparametric analysis of a one-way layout. It is highly robust against outliers and errors in data. Further, we use MannWhitney test which performs a two-sample Wilcoxon rank sum of the equality of two population medians. All these non-parametric tests are robust in the presence of outliers, as is the case with financial markets data.

Many studies have used the dummy variable methodology to detect seasonality in market variables. Chien, Lee and Wang (2002) provide statistical analysis and empirical evidence that the methodology may provide misleading results. We avoid this methodology and use the methodology developed by Hamid and Dhakar (2008). Unless otherwise stated, significance is at 5\% level.

\section{DATA SOURCE AND DESCRIPTIVE STATISTICS}

Monthly returns data for large and small stocks are taken from "Stocks, Bonds, Bills and Inflation Yearbook 2014”. Large stocks are represented by S\&P 500 Composite Index with dividend reinvestment. It is S\&P 500 stocks from 1957 to the present; from 1926 to 1956, it is S\&P 90. Small company stocks are represented by fifth capitalization quintile of stocks on the NYSE for 1926 to 1 o 1981; performance of the Dimensional Funds Association (DFA) Small Company Fund represents from 1982 to March 2001; performance of the DFA Micro Cap Fund represents from April 2001 to the present. The data is broken up into returns in the form of capital appreciation, and income returns.

We have 1,056 monthly total returns for large and small stocks. 
FIGURE 1A

HISTOGRAM AND SUMMARY FOR MONTHLY RETURNS: LS: 1926 TO 2013

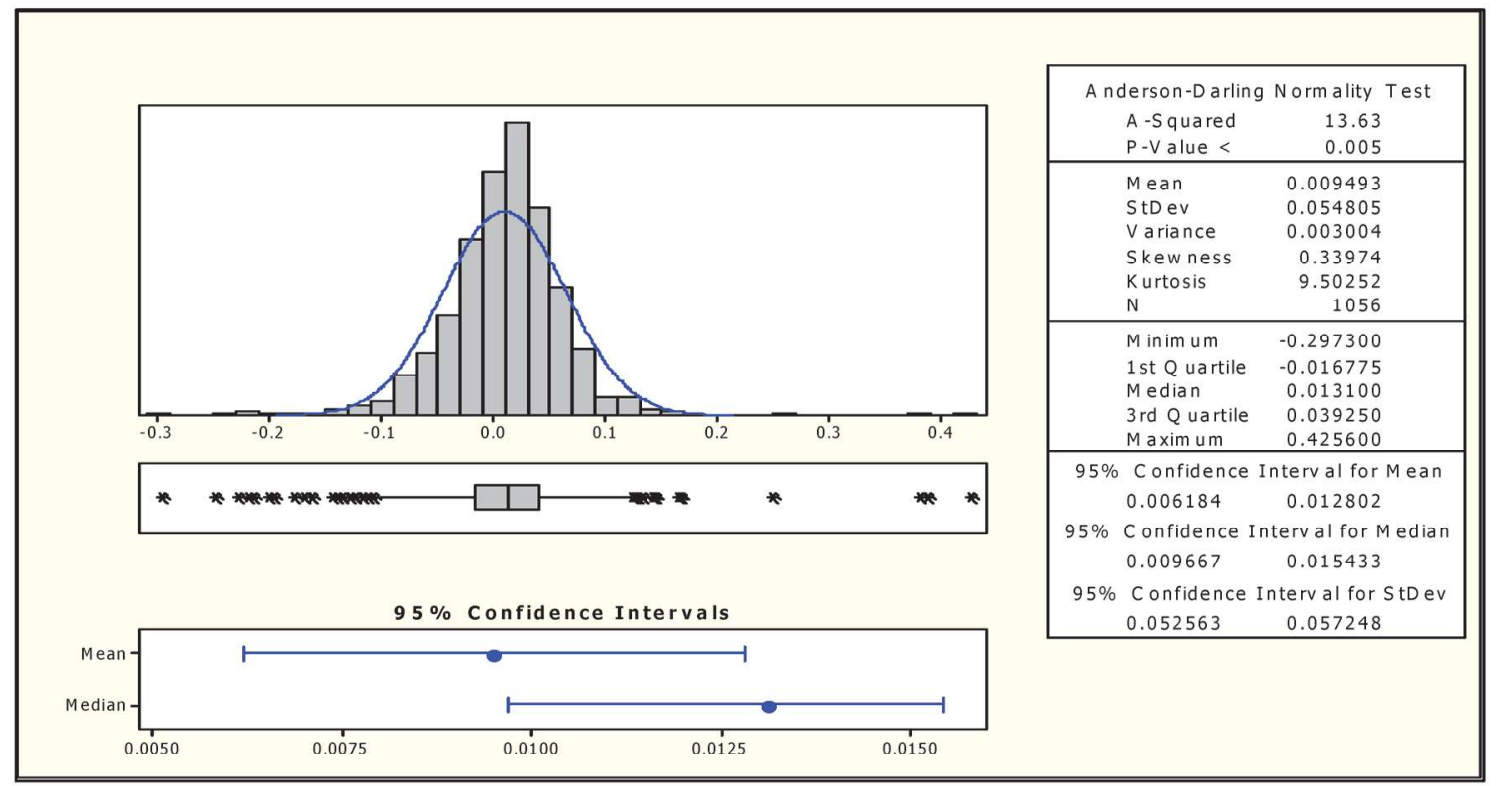

Figure $1 \mathrm{~A}$ above shows the mean of monthly returns of large stocks: $0.9493 \%$ (or an annualized return of $11.39 \%$ ). Figure 1B shows the mean of monthly returns of small stocks: $1.31 \%$ (or $15.72 \%$ annualized). The standard deviation of monthly returns of large stocks is $5.4805 \%$ which translates to an annualized standard deviation of $18.9850 \%$. Figure 1B shows the standard deviation of monthly returns of small stocks is $8.2951 \%$ which translates to an annualized standard deviation of $28.7351 \%$ ). The histograms below show the slightly skewed distribution for both types of stocks - more for small stocks which reflects greater incidence of outliers for small stocks. Both, the Skewness and the Kurtosis statistics for large and small stocks violate normality assumption. The Jarque-Bera statistics of the two (186.69 for small stocks and 200.64 for small stocks) also imply the normality assumption is violated. 
FIGURE 1B

HISTOGRAM AND SUMMARY FOR MONTHLY RETURNS: SS: 1926 TO 2013

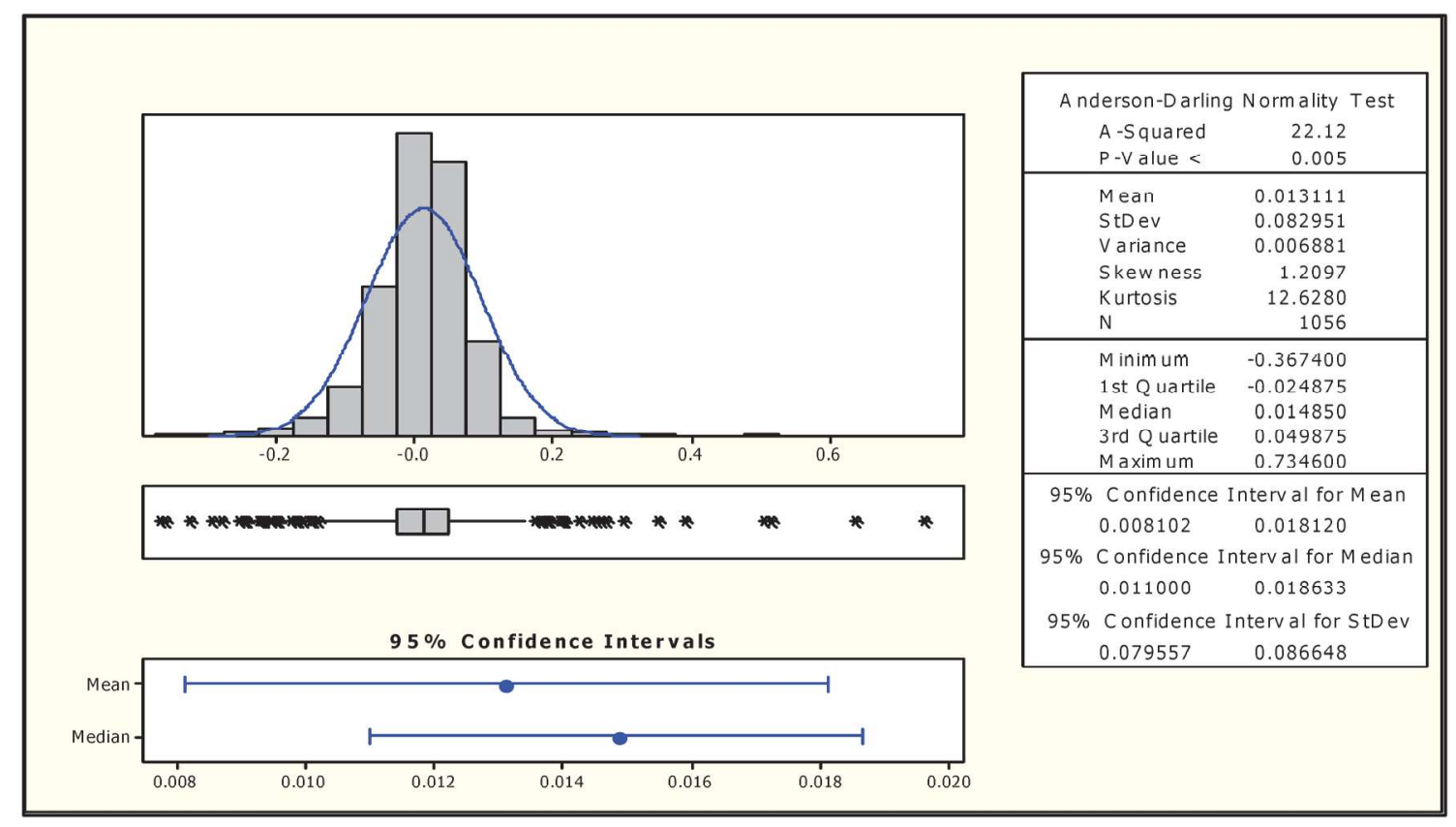

\section{ANALYSIS OF RESULTS}

We look at the behavior of large stocks and small stocks by testing the three hypotheses above for the full data set (1926 to 2013).

\section{Large Stocks: 1926-2013}

The 88 year period consists of 1,056 months. As shown earlier in Figure 1A, and as also shown in Table 1 below, the mean of monthly returns for the entire period is $0.95 \%$ and is significantly greater than zero. The mean monthly return of July is the highest $(1.79 \%)$, followed by December $(1.71 \%)$, April $(1.53 \%)$, November $(1.40 \%)$, and January (1.37\%). All of these returns are significantly greater than zero. But none of these returns are significantly greater than the mean returns of other eleven months stacked. This finding pretty closely follows the means of monthly changes found for the Dow Jones Industrial Average by Hamid and Dhakar (2016) for the period 1896 to 2013 and by Lakonishok and Smidt (1988) for the period 1896 to 1986 . The mean return for September $(-0.76 \%)$ is significantly lower than the mean return of the other eleven months stacked. However, December's mean return is significantly higher from the other months for a $\mathrm{p}$ value of 0.052 . So we have a negative September effect for large stocks which was also found by Hamid and Dhakar (2014). We find month effect in terms of variances of monthly returns for April (higher variance), and January, February, and December (lower variances). 
TABLE 1

DESCRIPTIVE STATISTICS AND MONTHLY SEASONALITY OF LARGE STOCKS: 1926-2013

\begin{tabular}{|l|r|r|r|r|r|r|r|r|r|r|r|r|r|}
\hline & \multicolumn{1}{c|}{ All } & \multicolumn{1}{c|}{ Jan } & \multicolumn{1}{c|}{ Feb } & Mar & Apr & May & Jun & \multicolumn{1}{l}{ Jul } & Aug & Sep & Oct & Nov & Dec \\
\hline Count & 1056 & 88 & 88 & 88 & 88 & 88 & 88 & 88 & 88 & 88 & 88 & 88 & 88 \\
\hline Mean & 0.95 & 1.37 & 0.37 & 0.72 & 1.53 & 0.51 & 0.98 & 1.79 & 1.29 & -0.76 & 0.50 & 1.40 & 1.71 \\
\hline Median & 1.31 & 1.66 & 0.77 & 1.18 & 1.32 & 1.37 & 0.32 & 1.44 & 1.61 & 0.01 & 0.95 & 1.88 & 1.82 \\
\hline Minimum & -29.73 & -8.43 & -17.72 & -24.87 & -19.97 & -22.89 & -16.25 & -11.32 & -14.46 & -29.73 & -21.52 & -12.46 & -14.00 \\
\hline Maximum & 42.56 & 13.43 & 11.93 & 11.01 & 42.56 & 16.83 & 25.03 & 38.15 & 38.69 & 16.73 & 16.57 & 12.92 & 11.43 \\
\hline Range & 72.29 & 21.86 & 29.65 & 35.88 & 62.53 & 39.72 & 41.28 & 49.47 & 53.15 & 46.46 & 38.09 & 25.38 & 25.43 \\
\hline Std Dev & 5.48 & 4.73 & 4.22 & 5.05 & 6.64 & 5.66 & 5.31 & 6.13 & 6.18 & 5.97 & 6.16 & 5.13 & 3.58 \\
\hline p-value (m=0) & 0.00 & 0.01 & 0.41 & 0.19 & 0.03 & 0.40 & 0.09 & 0.01 & 0.05 & 0.23 & 0.45 & 0.01 & 0.00 \\
\hline p-value (t test) & & 0.39 & 0.20 & 0.65 & 0.39 & 0.45 & 0.96 & 0.18 & 0.59 & 0.01 & 0.47 & 0.40 & 0.05 \\
\hline p-value (F test) & & 0.03 & 0.00 & 0.14 & 0.01 & 0.35 & 0.35 & 0.07 & 0.06 & 0.12 & 0.06 & 0.20 & 0.00 \\
\hline Mean Return & Pos & Pos & & & Pos & & & Pos & & & & Pos & Pos \\
\hline $\begin{array}{l}\text { Mo Effect } \\
\text { (Mean) }\end{array}$ & & & & & & & & & & & & & \\
\hline $\begin{array}{l}\text { Mo Effect } \\
\text { (Var) }\end{array}$ & & Lower & Lower & & Higher & & & & & & & & Lower \\
\hline
\end{tabular}

Note: "Pos" implies the mean of monthly changes was significantly greater than zero; "Neg" implies the mean of monthly changes was significantly less than zero; "Higher" implies the mean or the variance of monthly changes for a month was significantly higher than those of the other months; "Lower" implies the mean or the variance of monthly changes for a month was significantly lower than those of the other months. Numbers are rounded in all tables to two decimal places.

However, two non-parametric tests show no significant difference in the medians of the monthly returns of large stocks. Kruskal-Wallis H-statistic $=16.45(\mathrm{p}=0.125)$; Mood's Median test yields a Chisquare of 15.83 ( $\mathrm{p}=0.148$ ). Kruskal-Wallis test does show September does have the lowest median return (but positive) and December does have the highest median return.

\section{Small Stocks: 1926-2013}

Table 2 shows the mean of monthly returns for the entire period is $1.31 \%$ and is significantly greater than zero. The mean monthly return of January is the highest $(5.84 \%)$, followed by July $(1.90 \%)$, February $(1.53 \%)$, and December $(1.44 \%)$. All of these returns are significantly greater than zero. The mean return of January is significantly higher $(p=0.00)$ than the mean return of the other eleven months stacked. The mean return for October $(-0.68 \%)$ is significantly lower $(p=0.02)$ than the mean return of the other eleven months stacked. The mean return of September is lower than the mean of the other eleven months stacked for a $p$ value of 0.07 . So we have a positive January effect and a negative October effect for small stocks. However, this finding is based on fifth capitalization quintile of stocks on the NYSE at least for the period 1926 to 1981 and the NYSE stocks are comparatively larger than the small stocks that other researchers considered. We would not expect to find positive January effect with even the smallest of the NYSE stocks because they are significantly large. We do find a negative September effect (as with large stocks) but significant for a $p$ value of 0.07 . We also find May and August exhibiting significantly higher variances compared to that of other eleven months stacked, and lower variances for February, November, and December. September's variance is significantly higher but for a $p$ value of 
0.09. These findings for both large and small stocks go against the concept of efficiency of the markets and present possible profitable investment opportunities.

TABLE 2

DESCRIPTIVE STATISTICS AND MONTHLY SEASONALITY OF SMALL STOCKS: 1926-2013

\begin{tabular}{|l|r|r|r|r|r|r|r|r|r|r|r|r|r|}
\hline & \multicolumn{1}{c|}{ All } & \multicolumn{1}{c|}{ Jan } & \multicolumn{1}{c|}{ Feb } & Mar & Apr & May & Jun & \multicolumn{1}{l|}{ Jul } & Aug & Sep & Oct & Nov & Dec \\
\hline Count & 1056 & 88 & 88 & 88 & 88 & 88 & 88 & 88 & 88 & 88 & 88 & 88 & 88 \\
\hline Mean & 1.31 & 5.84 & 1.53 & 0.55 & 1.36 & 0.68 & 0.95 & 1.90 & 1.30 & -0.42 & -0.68 & 1.29 & 1.44 \\
\hline Median & 1.49 & 4.82 & 1.38 & 1.47 & 1.68 & 0.60 & 0.47 & 1.33 & 1.26 & 0.30 & 0.49 & 2.24 & 1.70 \\
\hline Minimum & -36.74 & -8.48 & -13.11 & -36.00 & -22.20 & -36.74 & -21.68 & -22.59 & -20.10 & -32.46 & -29.19 & -19.62 & -21.95 \\
\hline Maximum & 73.46 & 38.91 & 25.66 & 14.45 & 50.38 & 63.39 & 34.98 & 35.23 & 73.46 & 51.45 & 21.36 & 14.12 & 12.41 \\
\hline Range & 110.20 & 47.39 & 38.77 & 50.45 & 72.58 & 100.13 & 56.66 & 57.82 & 93.56 & 83.91 & 50.55 & 33.74 & 34.36 \\
\hline Std Dev & 8.30 & 8.39 & 6.44 & 7.43 & 9.32 & 9.93 & 7.65 & 7.99 & 9.76 & 9.17 & 8.26 & 7.03 & 5.76 \\
\hline p-value (m=0) & 0.00 & 0.00 & 0.03 & 0.49 & 0.17 & 0.52 & 0.25 & 0.03 & 0.21 & 0.67 & 0.44 & 0.09 & 0.02 \\
\hline p-value (t test) & & 0.00 & 0.75 & 0.32 & 0.95 & 0.53 & 0.65 & 0.48 & 0.99 & 0.07 & 0.02 & 0.98 & 0.84 \\
\hline p-value (F test) & & 0.39 & 0.00 & 0.08 & 0.07 & 0.01 & 0.15 & 0.32 & 0.02 & 0.09 & 0.51 & 0.02 & 0.00 \\
\hline Mean Return & Pos & Pos & Pos & & & & & Pos & & & & & Pos \\
\hline $\begin{array}{l}\text { Mo Effect } \\
\text { (Mean) }\end{array}$ & & & & & & & & & & & & \\
\hline $\begin{array}{l}\text { Mo Effect } \\
\text { (Var) }\end{array}$ & & & & & & & & & & & & & \\
\hline
\end{tabular}

Note: See note under Table $3 \mathrm{~A}$; numbers are rounded to two decimal places.

Two non-parametric tests show significant difference in the medians of the monthly returns of large stocks. Kruskal-Wallis H-statistic $=37.75(\mathrm{p}=0.00)$; Mood's Median test yields a Chi-square of 25.27 $(p=0.01)$. January's median is the highest $(4.82 \%)$ followed by December's median $(1.70 \%)$. Nonparametric tests lend further support to seasonality in monthly returns of small stocks.

Figure 2A shows the cyclicity of large stock returns and the dip of the mean of returns from July to September, and the subsequent increase until December. Short term traders stand to gain by shorting in July and buying back in September, or buying in September and selling in December. 
FIGURE 2A

MEAN OF MONTHLY RETURNS: LARGE STOCKS: 1926 TO 2013

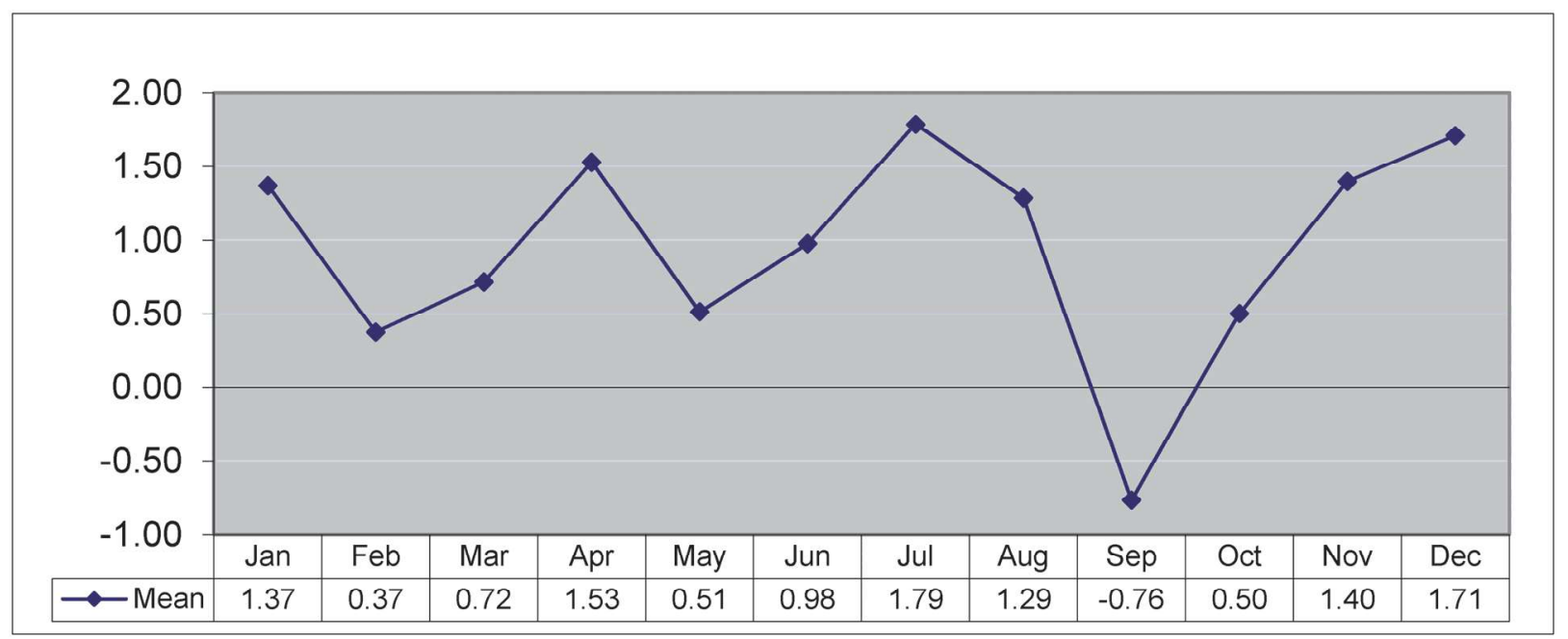

Figure 2B shows the general downward trend of small stock returns all the way to September and October (negative mean only for these two months) and the subsequent increase until December.

FIGURE 2B

MEAN OF MONTHLY RETURNS: SMALL STOCKS: 1926 TO 2013

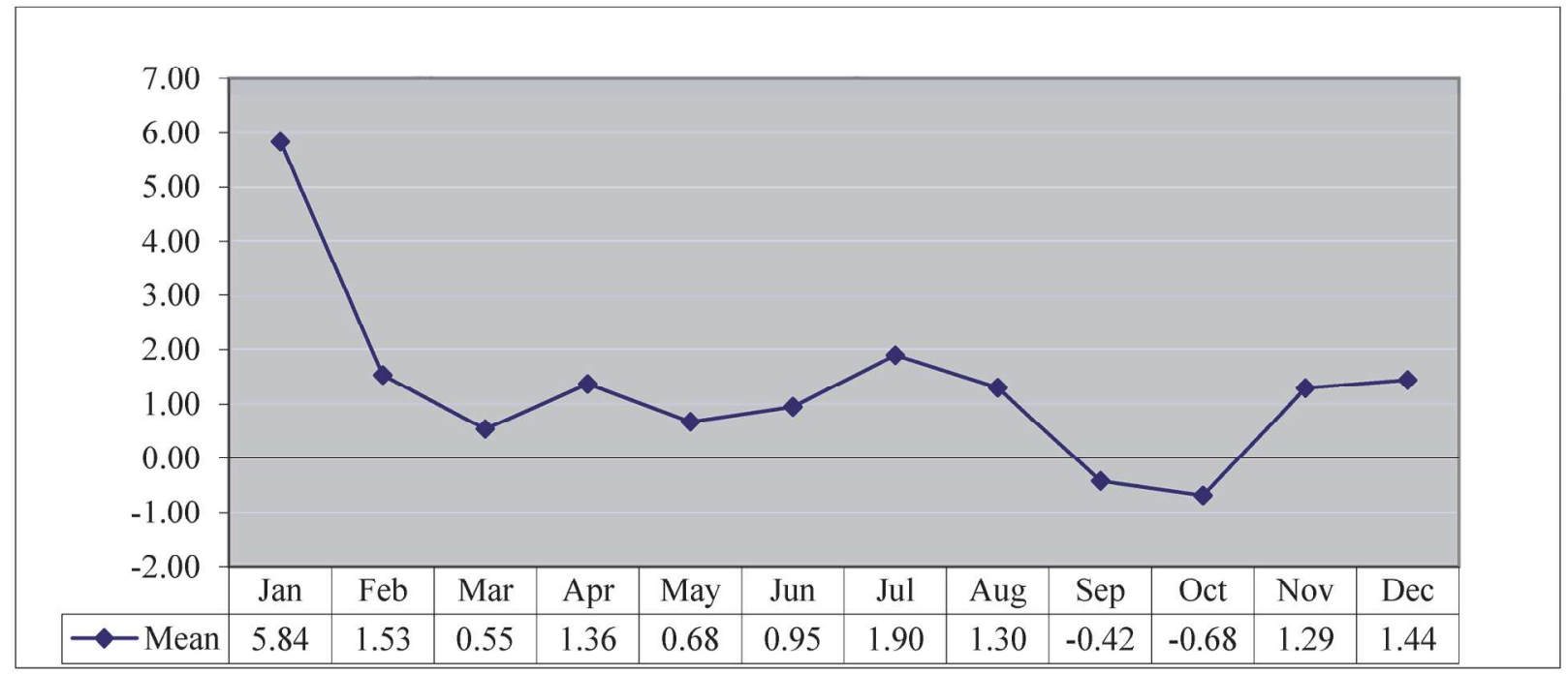

Short term traders stand to gain on average by shorting small stocks in January and buying back in March or April. Another month to short sell is July and then buying back in September or October. The other potentially profitable approach is to buy in September or October and sell in January. For seven of the twelve months mean of returns are between $1 \%$ and $2 \%$. The highly pronounced cyclicity for large stocks and less pronounced cyclicity for small stocks go contrary to efficient markets hypothesis. 


\section{Comparison of Returns and Volatilities of Large and Small Stocks}

The mean return of large stocks is lower $(0.95 \%)$ compared to the mean return of small stocks $(1.31 \%)$, but the difference is not highly significant based on parametric t-test $(\mathrm{p}=0.24)$. The median of monthly returns of large stocks $(1.31 \%)$ is lower compared to that of small stocks $(1.49 \%)$, but the medians of the two types of stocks are also not significantly different based on two nonparametric tests (Kruskal-Wallis H-statistic $=1.76(\mathrm{p}=0.18)$; Moods Median test yields a Chi-square of $0.48(\mathrm{p}=0.49)$. However the difference in their medians is significant based on Mann-Whitney two sample rank sum test $(p=0.00)$. Also, the standard deviations of the two types of stocks are significantly different $(p=0.00)$ based on F-test.

\section{SUMMARY AND CONCLUSION}

For large stocks, we find a negative September effect in their monthly returns for the period 1926 to 2013 (September's mean monthly return being significantly lower than the mean of the monthly returns of the other eleven month's stacked). The mean return of December is higher than the mean of the other eleven months stacked for a $\mathrm{p}$ value of 0.052 . April underwent significantly higher variance compared to that of the other eleven months stacked. For small stocks, we find a January effect (January's mean return being significantly greater than the mean of the monthly returns of the other eleven months stacked). Also, we find a negative October effect (October's mean return is significantly lower than the mean of the other eleven months stacked). The negative September effect for large stocks and positive January and negative October effect for small stocks are inexplicable anomalies and go against the concept of efficient markets. The January effect dates back to Wachtel (1942) and it has persisted in small stock returns. We also find significantly greater volatility of monthly returns for April when it comes to large stocks; January, February, and December have significantly lower volatilities compared to those of the other eleven months stacked. For small stocks, volatility is significantly higher in May and in August; it is lower in February, November and December. Thus, find significantly lower volatility in February and in December for both large and small stocks. Overall, large and small stock are not as efficiently priced as the proponents of efficient markets hypothesis would want us to believe. 


\section{REFERENCES}

Agrawal, A. and K. Tandon. (1994). Anomalies or Illusions?: Evidence from Stock Markets in Eighteen Countries, Journal of International Money and Finance, 13, 83-106.

Angelovska, J. (2014). Month Related Seasonality on the Macedonian Stock Market, Business and Economics Research, Vol. 5, Issue 1, 143-150.

Arbel, A. and P. J. Strebel. (1983). Giraffes, Institutions and Neglected Firms. Financial Analysts Journal, May-June, 57-63.

Baker, R. and R. Limmack. (1998). Firm Size, Monthly Seasonalities and Tax Loss Selling: Further Evidence from the UK, British Accounting Review, 30, $221-248$.

Bachelier, L. (1900). Theorie de la Speculation. Paris, Gauthier-Villars, reprinted 1964, in P. Cootner, ed.: The Random Character of Stock Market Prices (Massachusetts Institute of Technology, Cambridge, Massachusetts), $17-78$.

Banz, R. (1981). The Relationship between Return and Market Value of Common Stocks, Journal of Financial Economics, 9(1), 3 - 18.

Berk J. (1995). A Critique of Size Related Anomalies, Review of Financial Studies, 8(2), 275 - 286.

Blume, M. E. and R. F. Stambaugh. (1983). Biases in Computed Returns: An Application to the Size Effect, Journal of Financial Economics, 12(3), 387-404.

Brown, P., D. Keim, W. Kelidon and T. Marsh. (1983). Stock Return Seasonalities and the Tax Loss Selling Hypothesis: Analysis of the Arguments and Australian Evidence, Journal of Financial Economics, 2(1), 105 - 123.

Chien, Chin-Chen, Cheng-few Lee and Andrew M. L. Wang. (2002). A note on stock market seasonality: The impact of stock price volatility on the application of dummy variable regression model. The Quarterly Review of Economics and Finance, 42, 155-162.

Cowles, A. (1933). Can Economic Forecasters Forecast?, Econometrica, 7(3), 229 - 263.

Cowles, A. I. And H. Jones. (1937). Some a Posteori Probabilities in Stock Market Action. Econometrica, $5,280-294$.

Fama, E. (1965). The Behavior of Stock Market Prices, Journal of Business, 38, 34 - 105.

Fama, E. (1970). Efficient Capital Markets: A Review of Theory and Empirical Work. Journal of Finance, 25(2), $383-417$.

Fama, E. and K. French. (1992). The Cross-Section of Expected Returns. Journal of Finance, 47, 427 465.

Friday, H.S. and N. Hoang. (2015). Seasonality in the Vietnam Stock Index. The International Journal of Business and Finance Research, 9(1), 103-112.

Garza-Gomez, X., J. Hodoshima and M. Kunimura. (1998). Does Size Really Matter in Japan. Financial Analysts Journal, 54, 22 - 34.

Giovanis, E. (2009). Calendar Effects in Fifty-five Stock Market Indices, Global Journal of Finance and Management, 1(2), 75-98.

Hamid, Shaikh A. and Tej S. Dhakar. (2008). The Behavior of the US Consumer Price Index 1913-2003: A Study of Seasonality in the Monthly US CPI. Journal of Applied Economics, 40(13).

Hamid, Shaikh A. and Tej S. Dhakar. (2016). Seasonality in the Monthly Changes of DJIA: 1896 to 2013. Forthcoming in Journal of Business and Behavioral Sciences.

Haugen, R. and P. Jorion. (1996). The January Effect: Still Here after All These Years. Financial Analysts Journal, 52(1), $27-31$.

Kato, K. and J. Schallheim. (1985). Seasonal and Size Anomalies in the Japanese Stock Market. Journal of Financial and Quantitative Analysis, 20(2), 243 - 260.

Keim, D. (1983). Size Related Anomalies and Stock Market Seasonality: Further Empirical Evidence. Journal of Financial Economics, 12, 12 - 32.

Kendall, M. (1953). The Analysis of Economics Time Series: Part 1: Prices, in P. Cootner, ed.: The Random Character of Stock Prices, (MIT Press, Cambridge). 
Lakonishok, J. and S. Smidt. (1988). Are Seasonal Anomalies Real? A Ninety Year Perspective. Journal of Financial Studies, 1(4), 403 - 425.

Mandelbrot, B. (1966). Forecasts of Future Prices, Unbiased Markets, and Martingale Models. Journal of Business, 39, $242-255$.

Officer, R. (1975). Seasonality in Australian Capital Markets. Journal of Financial Economics, 2, 29 51.

Osborne, M. F. M. (1959). Brownian Motion in the Stock Market. Operations Research, 7, 145 - 173.

Osborne, M. F. M. (1962). Periodic Structure in the Brownian Motion of Stock Prices. Operations Research, 10, $345-379$.

Reinganum, M. (1981). Misspecification of Capital Asset Pricing: Empirical Anomalies Based on Earnings Yield and Market Values. Journal of Financial Economics, 9, $19-46$.

Riepe, M. (1998). Is Publicity Killing the January Effect? Journal of Financial Planning, 11, 64 - 70.

Riepe, M. (2001). The January Effect: Not Dead Yet But Not at All Well. Journal of Financial Planning, $14,44-47$.

Roll, R. (1983). Vas Is Das? Journal of Portfolio Management, 9, 18 - 28.

Rozeff, M. and W. Kinney. (1976). Capital Market Seasonality - the Case of Stock Returns. Journal of Financial Economics, 3, 379 - 402.

Samuelson, P. (1965). Proof That Properly Anticipated Prices Fluctuate Randomly. Industrial Management Review, 6, $41-49$.

Wachtel, S. B. (1942). Certain Observations on Seasonal Movements in Stock Prices. Journal of Business, 15, $184-193$.

Working, H. (1934). A Random Difference Series for Use in the Analysis of Time Series. Journal of the American Statistical Association, 29, 11 - 24. 